\title{
Choriodecidual leukocytes display a unique gene expression signature in spontaneous labor at term
}

\author{
Marcia Arenas-Hernandez ${ }^{1,2}$ • Nardhy Gomez-Lopez ${ }^{3}$. Valeria Garcia-Flores ${ }^{4}$ - Claudia Rangel-Escareño ${ }^{5}$.

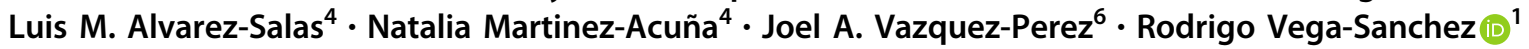

Received: 1 September 2017 / Revised: 1 November 2017 / Accepted: 16 November 2017 / Published online: 24 January 2018

(c) The Author(s) 2018. This article is published with open access

\begin{abstract}
Prior to and during the process of human labor, maternal circulating leukocytes infiltrate the maternal-fetal interface (choriodecidua) and become activated resembling choriodecidual leukocytes. Since, there is no evidence comparing maternal circulating and choriodecidual leukocytes, herein, we characterized their transcriptome and explored the biological processes enriched in choriodecidual leukocytes. From women undergoing spontaneous term labor we isolated circulating and choriodecidual leukocytes, performed microarray analysis $(n=5)$ and qRT-PCR validation $(n=9)$ and interaction network analysis with up-regulated genes. We found 270 genes up-regulated and only 17 genes down-regulated in choriodecidual leukocytes compared to maternal circulating leukocytes. The most up-regulated genes were CCL18, GPNMB, SEPP1, FN1, RNASE1, SPP1, C1QC, and PLTP. The biological processes enriched in choriodecidual leukocytes were cell migration and regulation of immune response, chemotaxis, and humoral immune responses. Our results show striking differences between the transcriptome of choriodecidual and maternal circulating leukocytes. Choriodecidual leukocytes are enriched in immune mediators implicated in the spontaneous process of labor at term.
\end{abstract}

Electronic supplementary material The online version of this article (https://doi.org/10.1038/s41435-017-0010-z) contains supplementary material, which is available to authorized users.

Nardhy Gomez-Lopez

nardhy.gomez-lopez@wayne.edu

$\triangle$ Rodrigo Vega-Sanchez

r.vega@inper.mx

vegarodrig@gmail.com

1 Departamento de Nutrición y Bioprogramación, Instituto Nacional de Perinatología Isidro Espinosa de los Reyes, Mexico City, MEX, Mexico

2 Departamento de Biomedicina Molecular, Centro de Investigación y de Estudios Avanzados, Instituto Politécnico Nacional, Mexico City, MEX, Mexico

3 Department of Obstetrics and Gynecology \& Immunology and Microbiology, Wayne State University School of Medicine, Perinatal Research Initiative in Support of the Perinatology Research Branch, Detroit, MI, USA

4 Departamento de Genética y Biología Molecular, Centro de Investigación y de Estudios Avanzados, Instituto Politécnico Nacional, Mexico City, MEX, Mexico

5 Departamento de Genómica Computacional, Instituto Nacional de Medicina Genómica, Mexico City, MEX, Mexico

6 Departamento de Micología y Virología, Instituto Nacional de Enfermedades Respiratorias, Mexico City, MEX, Mexico

\section{Introduction}

Labor is recognized as a physiological process of sterile inflammation [1-5], characterized by the infiltration of immune cells into the cervix [6-9], myometrium [8, 10-12], and maternal-fetal interface [8, 13-16]. This interface includes two areas of contact between the mother and the fetus: the decidua parietalis, which lines the uterine cavity not covered by the placenta and is juxtaposed to the chorion laeve; and the decidua basalis, which lays on the basal plate of the placenta and is invaded by the interstitial trophoblast $[16,17]$. Decidua parietalis is composed of stroma-type cells, glandular cells, and leukocytes [18-21], and the portion that is attainable is attached to the chorioamniotic membranes; therefore, this anatomical site is known as the choriodecidua [16]. Since the choriodecidua represents the major site of fetal antigenic exposure to the maternal immune system, our studies have focused on understanding the mechanisms whereby maternal leukocytes are recruited into the maternal-fetal interface and their role in the processes of term and preterm labor [22].

The current hypothesis is that the chorioamniotic membranes exhibit chemotactic processes driven by specific chemokines in order to recruit maternal circulating 
Fig. 1 Heat map representation of the differentially expressed genes in the choriodecidual leukocytes or maternal circulating leukocytes from women who underwent spontaneous labor at term. Heat map displays the unsupervised hierarchical clustering of the 775 genes demonstrating the transcriptomic changes of choriodecidual leukocytes and maternal circulating leukocytes. The negative $z$-score indicates the downregulated genes (shown in green), and the positive $z$-score indicates the up-regulated genes (shown in red). The labels on the top of the heat map indicate individual women samples $(n=5$ each)

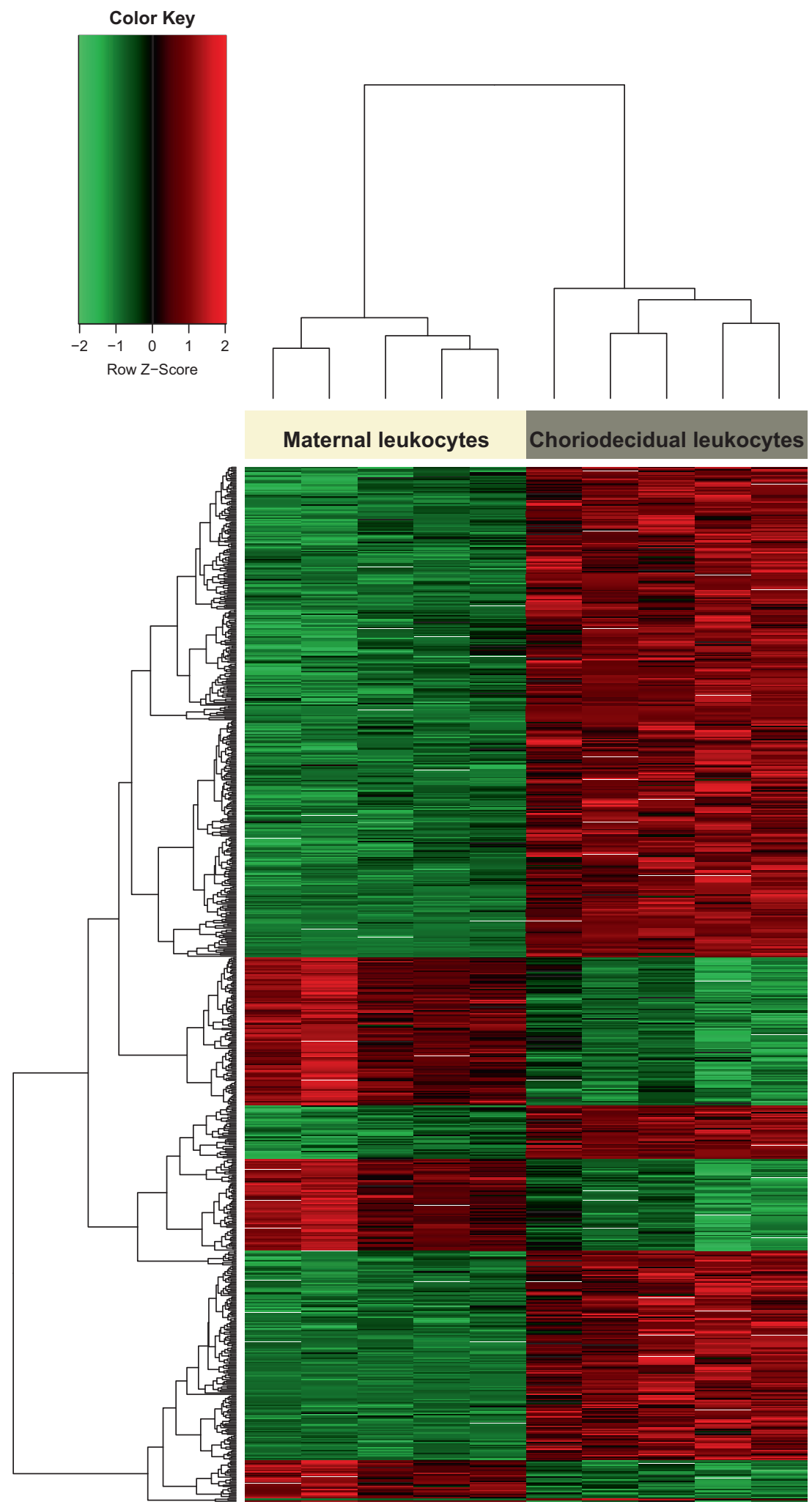

leukocytes into the choriodecidua [14, 16, 23-25]. In addition, the responsiveness of peripheral leukocytes to be attracted to chemotactic stimuli derived from the chorioamniotic membranes seems to be a key feature in this process [26]. Consistent with such a hypothesis, previous studies have demonstrated that peripheral leukocytes 


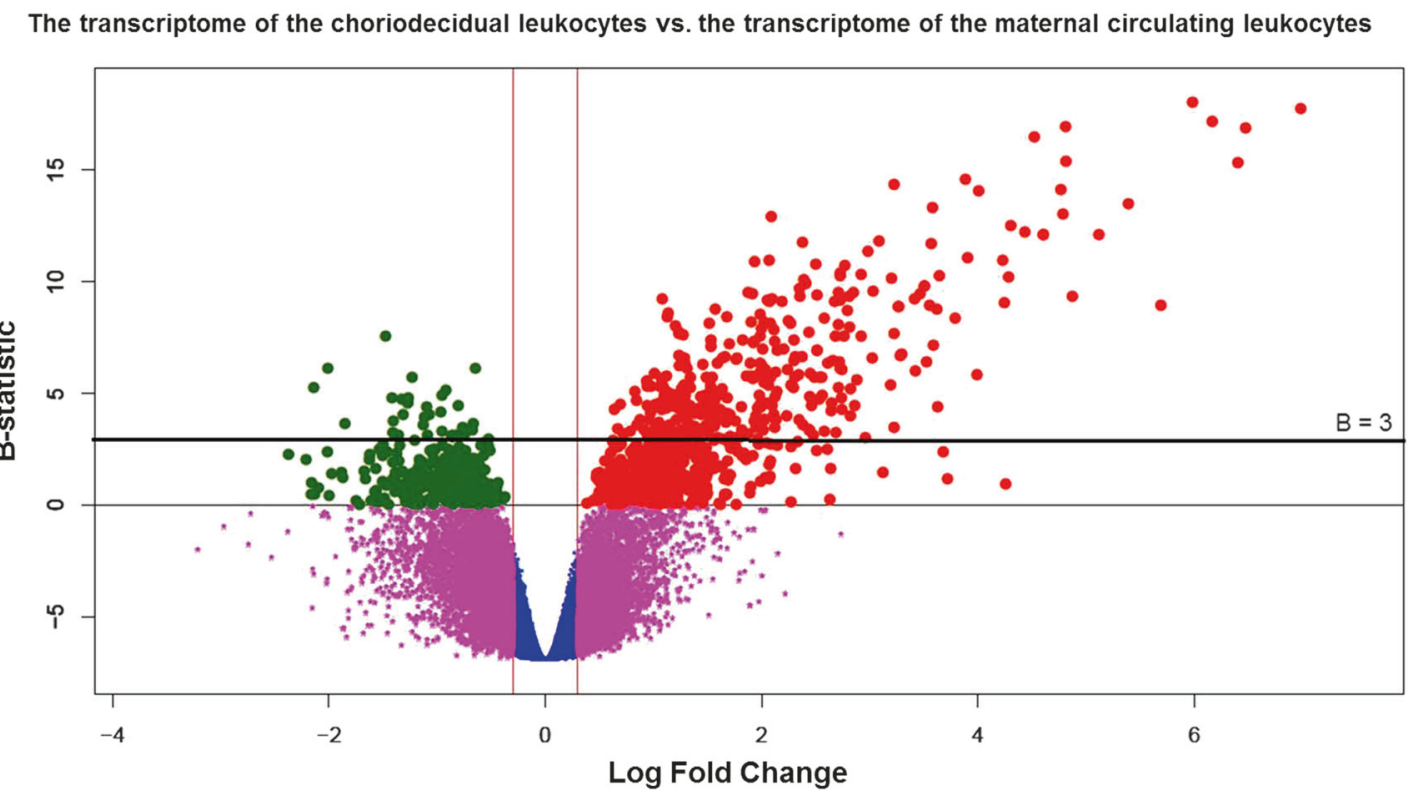

Fig. 2 Volcano plot displaying the differentially expressed genes between choriodecidual leukocytes and maternal circulating leukocytes from women who underwent spontaneous labor at term. Bstatistic values are plotted against the log fold change (base 2). A Bstatistic of zero corresponds to a 50-50 chance that the gene is differentially expressed (gray line). A B-statistic of $\geq 3$ indicates a $95.3 \%$

displayed increased chemotactic activity and cytokine production during the process of labor [27, 28], resembling an inflammatory phenotype similar to that observed in pathological conditions [29, 30]. Collectively, these data suggest that the chorioamniotic membranes, and most likely the decidual stromal cells, recruit maternal circulating leukocytes into the choriodecidua prior to and during the process of labor. Following recruitment, the choriodecidual leukocytes expressed cell adhesion molecules (CAMs) [16, 31-33] and labor mediators including cytokines/chemokines [14-16, 34] and matrix metalloproteinases (MMPs) [35]. All of which elicit cellmediated immune responses that participate in the process of labor [1, 36-38].

All of the above suggests that the maternal circulating leukocytes are activated prior to and during the process of labor and that their activation status may be similar to that expressed by the choriodecidual leukocytes. However, a direct comparison between the choriodecidual leukocytes and maternal circulating leukocytes during the process of labor at term has not been made. The aims of this study were: (1) to characterize the transcriptome of the choriodecidual leukocytes and maternal circulating leukocytes from the same woman undergoing spontaneous labor at term, and (2) to explore the biological processes enriched in these choriodecidual leukocytes. chance that the gene is differentially expressed (black line). On the $x$ axis, values outside the red lines represent log fold changes of $\geq 0.3$ between choriodecidual leukocytes and maternal circulating leukocytes. Red dots represent the up-regulated genes and green dots represent the down-regulated genes

\section{Results and discussion}

To our knowledge, this is the first study comparing the transcriptomic signatures of the choriodecidual leukocytes and maternal circulating leukocytes during the process of labor at term. Our first finding was that the transcriptome of the choriodecidual leukocytes was different from the transcriptome of the maternal circulating leukocytes. The heat map in Fig. 1 shows a mirrored image between the transcriptomic changes of choriodecidual leukocytes and maternal circulating leukocytes; in other words, upregulated genes in the choriodecidua were down-regulated in the maternal circulation and vice versa. Similarly, the volcano plot (Fig. 2) shows the differentially expressed genes between choriodecidual and maternal circulating leukocytes.

These results demonstrate that there are drastic differences between the transcriptome of the choriodecidual leukocytes compared to the maternal circulating leukocytes during the process of labor at term. Although there is no doubt that the maternal circulating leukocytes are activated prior to and during the process of labor [26-28], the findings, herein, support the concept that the maternal-fetal interface (decidua basalis and choriodecidua or decidua parietalis) is an enriched microenvironment that includes specific leukocyte subsets during the process of labor $[22$, 33]. 
Table 1 List of the top 100 differentially up-regulated genes between choriodecidual leukocytes and maternal circulating leukocytes

\begin{tabular}{|c|c|c|c|c|c|}
\hline Name & Symbol & $\begin{array}{l}\text { Log fold } \\
\text { change (base } \\
\text { 2) }\end{array}$ & $\begin{array}{l}\text { Fold } \\
\text { change }\end{array}$ & $B$-statistic & $\begin{array}{l}\text { Adjusted } P \text { - } \\
\text { value }\end{array}$ \\
\hline C-C motif chemokine ligand 18 & CCL18 & 6.98 & 126.50 & 17.77 & $3.7 \mathrm{E}-09$ \\
\hline Glycoprotein nmb & $G P N M B$ & 6.47 & 88.89 & 16.91 & $9.4 \mathrm{E}-09$ \\
\hline Selenoprotein P & $S E P P 1$ & 6.40 & 84.51 & 15.36 & $8.3 \mathrm{E}-08$ \\
\hline Fibronectin 1 & FN1 & 6.17 & 71.80 & 17.17 & $9.3 \mathrm{E}-09$ \\
\hline $\begin{array}{l}\text { Ribonuclease A family member } 1 \text {, } \\
\text { pancreatic }\end{array}$ & RNASE1 & 5.98 & 63.22 & 18.02 & $3.7 \mathrm{E}-09$ \\
\hline Secreted phosphoprotein 1 & $S P P 1$ & 5.69 & 51.59 & 8.94 & $2.9 \mathrm{E}-05$ \\
\hline Complement $\mathrm{C} 1 \mathrm{q} \mathrm{C}$ chain & $C 1 Q C$ & 5.39 & 41.93 & 13.49 & $7.2 \mathrm{E}-07$ \\
\hline Phospholipid transfer protein & PLTP & 5.12 & 34.70 & 12.08 & $2.6 \mathrm{E}-06$ \\
\hline $\mathrm{C}-\mathrm{C}$ motif chemokine ligand 2 & $C C L 2$ & 4.87 & 29.27 & 9.37 & $2.3 \mathrm{E}-05$ \\
\hline Cathepsin L & CTSL & 4.81 & 28.10 & 15.40 & $8.3 \mathrm{E}-08$ \\
\hline Formyl peptide receptor 3 & FPR3 & 4.81 & 28.05 & 16.94 & $9.4 \mathrm{E}-09$ \\
\hline Legumain & $L G M N$ & 4.78 & 27.54 & 13.01 & $1.1 \mathrm{E}-06$ \\
\hline Complement C1q B chain & $C 1 Q B$ & 4.76 & 27.18 & 14.10 & $3.5 \mathrm{E}-07$ \\
\hline Mannose receptor C-type 1 & $M R C 1$ & 4.60 & 24.33 & 12.12 & $2.6 \mathrm{E}-06$ \\
\hline Peripheral myelin protein 22 & $P M P 22$ & 4.52 & 22.94 & 16.47 & $1.8 \mathrm{E}-08$ \\
\hline Metallothionein $1 \mathrm{G}$ & $M T 1 G$ & 4.30 & 19.71 & 12.52 & $1.9 \mathrm{E}-06$ \\
\hline $\begin{array}{l}\text { Solute carrier organic anion } \\
\text { transporter family member } 2 \mathrm{~B} 1\end{array}$ & $S L C O 2 B 1$ & 4.28 & 19.47 & 10.18 & $1.3 \mathrm{E}-05$ \\
\hline Epithelial membrane protein & $E M P 1$ & 4.24 & 18.94 & 9.03 & $2.8 \mathrm{E}-05$ \\
\hline Metallothionein $1 \times$ & $M T 1 X$ & 4.23 & 18.75 & 10.96 & $7.3 \mathrm{E}-06$ \\
\hline $\begin{array}{l}\text { V-set and immunoglobulin domain } \\
\text { containing } 4\end{array}$ & VSIG4 & 4.01 & 16.07 & 14.08 & $3.5 \mathrm{E}-07$ \\
\hline $\begin{array}{l}\text { T-cell immunoglobulin and mucin } \\
\text { domain containing } 4\end{array}$ & TIMD4 & 3.99 & 15.89 & 5.82 & $3.2 \mathrm{E}-04$ \\
\hline Regulator of G-protein signaling 1 & $R G S 1$ & 3.90 & 14.95 & 11.10 & $6.6 \mathrm{E}-06$ \\
\hline Metallothionein 1E & $M T 1 E$ & 3.88 & 14.75 & 14.56 & $2.4 \mathrm{E}-07$ \\
\hline $\mathrm{C}-\times-\mathrm{C}$ motif chemokine ligand 10 & CXCL10 & 3.79 & 13.83 & 8.37 & $4.6 \mathrm{E}-05$ \\
\hline $\begin{array}{l}\text { Membrane spanning 4-domains } \\
\text { A4A }\end{array}$ & $M S 4 A 4 A$ & 3.64 & 12.48 & 10.27 & $1.2 \mathrm{E}-05$ \\
\hline $\begin{array}{l}\text { Oxidized low density lipoprotein } \\
\text { receptor } 1\end{array}$ & OLR1 & 3.63 & 12.35 & 4.39 & $8.2 \mathrm{E}-04$ \\
\hline Folate receptor beta & FOLR2 & 3.62 & 12.30 & 8.74 & $3.4 \mathrm{E}-05$ \\
\hline $\begin{array}{l}\text { Interferon alpha inducible protein } \\
27\end{array}$ & $I F I 27$ & 3.59 & 12.00 & 7.18 & $1.1 \mathrm{E}-04$ \\
\hline Complement C1q A chain & $C 1 Q A$ & 3.58 & 11.95 & 13.32 & $8.3 \mathrm{E}-07$ \\
\hline Apolipoprotein $\mathrm{C} 1$ & APOC1 & 3.57 & 11.85 & 11.67 & $3.6 \mathrm{E}-06$ \\
\hline Macrophage scavenger receptor 1 & MSRI & 3.55 & 11.73 & 8.94 & $2.9 \mathrm{E}-05$ \\
\hline Interleukin 6 & IL6 & 3.52 & 11.49 & 6.41 & $2.1 \mathrm{E}-04$ \\
\hline Complement $\mathrm{C} 2$ & $C 2$ & 3.50 & 11.34 & 9.80 & $1.8 \mathrm{E}-05$ \\
\hline CD80 molecule & CD80 & 3.42 & 10.70 & 6.03 & $2.7 \mathrm{E}-04$ \\
\hline $\begin{array}{l}\text { Ectonucleotide pyrophosphatase/ } \\
\text { phosphodiesterase } 2\end{array}$ & ENPP2 & 3.41 & 10.65 & 9.23 & $2.5 \mathrm{E}-05$ \\
\hline Matrix metallopeptidase 19 & MMP19 & 3.27 & 9.64 & 8.86 & $3.1 \mathrm{E}-05$ \\
\hline C-C motif chemokine ligand 13 & CCL13 & 3.22 & 9.34 & 7.70 & $7.7 \mathrm{E}-05$ \\
\hline Metallothionein $1 \mathrm{M}$ & MT1M & 3.22 & 9.34 & 3.50 & $1.6 \mathrm{E}-03$ \\
\hline $\begin{array}{l}\text { Nuclear protein } 1 \text {, transcriptional } \\
\text { regulator }\end{array}$ & NUPR1 & 3.22 & 9.33 & 14.32 & $3.0 \mathrm{E}-07$ \\
\hline
\end{tabular}


Table 1 (continued)

\begin{tabular}{|c|c|c|c|c|c|}
\hline Name & Symbol & $\begin{array}{l}\text { Log fold } \\
\text { change (base } \\
\text { 2) }\end{array}$ & $\begin{array}{l}\text { Fold } \\
\text { change }\end{array}$ & $B$-statistic & $\begin{array}{l}\text { Adjusted } P \text { - } \\
\text { value }\end{array}$ \\
\hline ADAM like decysin 1 & $A D A M D E C 1$ & 3.20 & 9.18 & 10.16 & $1.3 \mathrm{E}-05$ \\
\hline C-C motif chemokine ligand 4 & $C C L 4$ & 3.19 & 9.14 & 5.40 & $4.3 \mathrm{E}-04$ \\
\hline Neuropilin 2 & $N R P 2$ & 3.08 & 8.48 & 11.79 & $3.4 \mathrm{E}-06$ \\
\hline SLAM family member 8 & SLAMF8 & 3.03 & 8.17 & 9.57 & $2.2 \mathrm{E}-05$ \\
\hline Plasminogen activator, urokinase & PLAU & 3.02 & 8.12 & 6.60 & $1.8 \mathrm{E}-04$ \\
\hline $\begin{array}{l}\text { Chromosome } 15 \text { open reading } \\
\text { frame } 48\end{array}$ & C15orf48 & 2.96 & 7.77 & 3.00 & $2.2 \mathrm{E}-03$ \\
\hline Malic enzyme 1 & $M E 1$ & 2.92 & 7.57 & 10.33 & $1.2 \mathrm{E}-05$ \\
\hline Activating transcription factor 3 & $A T F 3$ & 2.92 & 7.56 & 7.58 & $8.4 \mathrm{E}-05$ \\
\hline DAB2, clathrin adapter protein & $D A B 2$ & 2.88 & 7.36 & 5.58 & $3.6 \mathrm{E}-04$ \\
\hline C-C motif chemokine ligand 8 & $C C L 8$ & 2.86 & 7.26 & 4.46 & $8.0 \mathrm{E}-04$ \\
\hline Formin like 2 & $F M N L 2$ & 2.85 & 7.20 & 9.51 & $2.2 \mathrm{E}-05$ \\
\hline CD163 molecule & $C D 163$ & 2.82 & 7.07 & 5.21 & $4.7 \mathrm{E}-04$ \\
\hline $\begin{array}{l}\text { Ral guanine nucleotide dissociation } \\
\text { stimulator like } 1\end{array}$ & $R G L 1$ & 2.81 & 7.03 & 7.98 & $6.2 \mathrm{E}-05$ \\
\hline $\begin{array}{l}\text { Sprouty related EVH1 domain } \\
\text { containing } 1\end{array}$ & SPREDI & 2.81 & 7.01 & 9.34 & $2.3 \mathrm{E}-05$ \\
\hline Neuropilin 2 & $N R P 2$ & 2.79 & 6.92 & 8.70 & $3.5 \mathrm{E}-05$ \\
\hline $\begin{array}{l}\text { Lipoma HMGIC fusion partner- } \\
\text { like } 2\end{array}$ & LHFPL2 & 2.77 & 6.81 & 10.74 & $8.3 \mathrm{E}-06$ \\
\hline Metallothionein 1A & $M T 1 A$ & 2.76 & 6.78 & 7.54 & $8.5 \mathrm{E}-05$ \\
\hline $\mathrm{C}-\mathrm{X}-\mathrm{C}$ motif chemokine ligand 2 & $C X C L 2$ & 2.74 & 6.69 & 4.31 & $8.7 \mathrm{E}-04$ \\
\hline Stearoyl-CoA desaturase & $S C D$ & 2.74 & 6.69 & 6.05 & $2.7 \mathrm{E}-04$ \\
\hline Solute carrier family 7 member 8 & SLC7A8 & 2.74 & 6.66 & 4.81 & $6.3 \mathrm{E}-04$ \\
\hline Phospholipase A2 group VII & PLA2G7 & 2.73 & 6.61 & 10.36 & $1.2 \mathrm{E}-05$ \\
\hline Transcobalamin 2 & TCN2 & 2.72 & 6.61 & 9.15 & $2.5 \mathrm{E}-05$ \\
\hline Chloride intracellular channel 2 & CLIC2 & 2.72 & 6.61 & 10.27 & $1.2 \mathrm{E}-05$ \\
\hline Lamin A/C & $L M N A$ & 2.72 & 6.60 & 6.10 & $2.6 \mathrm{E}-04$ \\
\hline C-C motif chemokine ligand 3 & $C C L 3$ & 2.72 & 6.57 & 6.40 & $2.1 \mathrm{E}-04$ \\
\hline $\begin{array}{l}\text { MER proto-oncogene, tyrosine } \\
\text { kinase }\end{array}$ & MERTK & 2.71 & 6.55 & 9.53 & $2.2 \mathrm{E}-05$ \\
\hline Olfactomedin like 2B & $O L F M L 2 B$ & 2.71 & 6.54 & 8.05 & $5.9 \mathrm{E}-05$ \\
\hline G protein-coupled receptor 34 & GPR34 & 2.71 & 6.53 & 5.27 & $4.5 \mathrm{E}-04$ \\
\hline $\begin{array}{l}\text { RasGEF domain family member } \\
\text { 1B }\end{array}$ & $R A S G E F 1 B$ & 2.68 & 6.42 & 3.26 & $1.8 \mathrm{E}-03$ \\
\hline GDNF family receptor alpha 2 & GFRA2 & 2.68 & 6.41 & 7.58 & $8.4 \mathrm{E}-05$ \\
\hline Serpin family E member 1 & SERPINE1 & 2.67 & 6.38 & 9.12 & $2.5 \mathrm{E}-05$ \\
\hline Serpin family F member 1 & SERPINF1 & 2.66 & 6.31 & 6.47 & $2.0 \mathrm{E}-04$ \\
\hline Epiregulin & $E R E G$ & 2.65 & 6.26 & 4.56 & $7.6 \mathrm{E}-04$ \\
\hline Interferon gamma & $I F N G$ & 2.64 & 6.24 & 4.20 & $9.5 \mathrm{E}-04$ \\
\hline $\begin{array}{l}\text { Nuclear receptor subfamily } 4 \text { group } \\
\text { A member } 1\end{array}$ & NR4A1 & 2.61 & 6.10 & 6.34 & $2.1 \mathrm{E}-04$ \\
\hline Amphiregulin & $A R E G$ & 2.58 & 5.97 & 3.28 & $1.8 \mathrm{E}-03$ \\
\hline $\begin{array}{l}\text { Hematopoietic prostaglandin D } \\
\text { synthase }\end{array}$ & $H P G D S$ & 2.58 & 5.97 & 8.38 & $4.6 \mathrm{E}-05$ \\
\hline \multirow[t]{2}{*}{ Metallothionein $1 \mathrm{H}$} & $M T 1 H$ & 2.56 & 5.89 & 4.94 & $5.9 \mathrm{E}-04$ \\
\hline & PHLDA1 & 2.56 & 5.88 & 5.73 & $3.2 \mathrm{E}-04$ \\
\hline
\end{tabular}


Table 1 (continued)

\begin{tabular}{|c|c|c|c|c|c|}
\hline Name & Symbol & $\begin{array}{l}\text { Log fold } \\
\text { change (base } \\
\text { 2) }\end{array}$ & $\begin{array}{l}\text { Fold } \\
\text { change }\end{array}$ & $B$-statistic & $\begin{array}{l}\text { Adjusted } P \\
\text { value }\end{array}$ \\
\hline \multicolumn{6}{|l|}{$\begin{array}{l}\text { Pleckstrin homology like domain } \\
\text { family A member } 1\end{array}$} \\
\hline Fatty acid binding protein 3 & $F A B P 3$ & 2.53 & 5.79 & 5.72 & $3.2 \mathrm{E}-04$ \\
\hline Heat shock protein family B & $H S P B 1$ & 2.53 & 5.78 & 4.72 & $6.7 \mathrm{E}-04$ \\
\hline $\begin{array}{l}\text { Acid phosphatase } 5 \text {, tartrate } \\
\text { resistant }\end{array}$ & $A C P 5$ & 2.51 & 5.71 & 9.43 & $2.2 \mathrm{E}-05$ \\
\hline CD69 molecule & $C D 69$ & 2.51 & 5.70 & 6.94 & $1.4 \mathrm{E}-04$ \\
\hline Sialic acid binding Ig like lectin 1 & SIGLEC1 & 2.49 & 5.61 & 5.75 & $3.2 \mathrm{E}-04$ \\
\hline Solute carrier family 30 member 1 & SLC30A1 & 2.47 & 5.56 & 3.16 & $2.0 \mathrm{E}-03$ \\
\hline $\mathrm{X}-\mathrm{C}$ motif chemokine ligand 2 & $X C L 2$ & 2.46 & 5.51 & 4.44 & $8.0 \mathrm{E}-04$ \\
\hline Metallothionein $1 \mathrm{~F}$ & $M T 1 F$ & 2.45 & 5.46 & 5.86 & $3.1 \mathrm{E}-04$ \\
\hline $\begin{array}{l}\text { Chemerin chemokine-like receptor } \\
1\end{array}$ & $C M K L R 1$ & 2.44 & 5.44 & 4.85 & $6.1 \mathrm{E}-04$ \\
\hline Metallothionein 1 pseudogene 3 & $M T 1 P 3$ & 2.41 & 5.31 & 9.93 & $1.6 \mathrm{E}-05$ \\
\hline Acid phosphatase 2, lysosoma & $A C P 2$ & 2.39 & 5.23 & 10.11 & $1.4 \mathrm{E}-05$ \\
\hline $\begin{array}{l}\text { Leukocyte immunoglobulin like } \\
\text { receptor B4 }\end{array}$ & LILRB4 & 2.38 & 5.20 & 11.77 & $3.4 \mathrm{E}-06$ \\
\hline Transferrin receptor & TFRC & 2.37 & 5.19 & 6.66 & $1.7 \mathrm{E}-04$ \\
\hline Tetraspanin 15 & TSPAN15 & 2.35 & 5.11 & 9.35 & $2.3 \mathrm{E}-05$ \\
\hline $\begin{array}{l}\text { Peroxisome proliferator activated } \\
\text { receptor gamma }\end{array}$ & PPARG & 2.35 & 5.09 & 9.68 & $2.0 \mathrm{E}-05$ \\
\hline Solute carrier family 1 member 3 & $S L C 1 A 3$ & 2.35 & 5.09 & 3.83 & $1.2 \mathrm{E}-03$ \\
\hline Colony stimulating factor 1 & CSF1 & 2.34 & 5.07 & 5.83 & $3.1 \mathrm{E}-04$ \\
\hline Serpin family $\mathrm{G}$ member 1 & SERPING1 & 2.31 & 4.96 & 6.65 & $1.8 \mathrm{E}-04$ \\
\hline Dual specificity phosphatase 10 & DUSP10 & 2.31 & 4.94 & 5.70 & $3.3 \mathrm{E}-04$ \\
\hline Solute carrier family 41 member 2 & SLC41A2 & 2.30 & 4.92 & 7.41 & $9.5 \mathrm{E}-05$ \\
\hline MAM domain containing 2 & $M A M D C 2$ & 2.30 & 4.91 & 5.24 & $4.6 \mathrm{E}-04$ \\
\hline $\begin{array}{l}\text { Nuclear receptor subfamily } 4 \text { group } \\
\text { A member } 3\end{array}$ & $N R 4 A 3$ & 2.27 & 4.82 & 5.36 & $4.4 \mathrm{E}-04$ \\
\hline
\end{tabular}

We found that choriodecidual leukocytes overexpressed several genes associated with cell migration and regulation of immune response. A total of 270 genes were upregulated while only 17 genes were down-regulated in the choriodecidual leukocytes compared to the maternal circulating leukocytes. The top 100 up-regulated genes are displayed in Table 1. The most up-regulated genes (fold change $>32$ ) in choriodecidual leukocytes, demonstrated by qRT-PCR (Table 2) were the following: (1) C-C motif chemokine ligand 18 (CCL18), (2) glycoprotein $\mathrm{nmb}$ $(G P N M B)$, (3) selenoprotein P (SEPP1), (4) fibronectin 1 $(F N 1)$, (5) ribonuclease A family member 1, pancreatic (RNASE1), (6) secreted phosphoprotein 1 (SPP1), (7) complement $\mathrm{Clq} \mathrm{C}$ chain $(C 1 Q C)$, and (8) phospholipid transfer protein $(P L T P)$.

These results coincide with previous studies demonstrating that choriodecidual leukocytes express CAMs [16, 39, 40], cytokines [8, 41, 42], chemokines [16, 34], and their receptors [16, 34, 43], enzymes [35, 44, 45], antimicrobial peptides [46], markers of activation [17, 39,4749], and even hormone receptors [50] before and during the process of labor. Together, these findings demonstrate that the choriodecidual leukocytes are a rich source of inflammatory mediators that can participate in the proinflammatory milieu that accompanies the process of labor.

The current study also demonstrated that the choriodecidual leukocytes from women who underwent spontaneous labor at term overexpressed genes implicated in the process of chemotaxis, including CCL2, CCL3, CCL4, and CXCL10. This finding is in line with previous studies demonstrating that the chorioamniotic membranes (including the decidua) exhibit leukocyte chemotaxis through the expression of these chemokines during the process of labor $[14,23,25,26]$. These results suggest that besides being a source of pro-inflammatory mediators, the choriodecidual leukocytes can actively participate in the process of 
Table 2 qRT-PCR validation in selected genes differentially expressed in the choriodecidual leukocytes and maternal circulating leukocytes

\begin{tabular}{|c|c|c|c|c|}
\hline \multirow[t]{2}{*}{ Gene name } & \multirow[t]{2}{*}{ Gene symbol } & \multicolumn{3}{|l|}{ qRT-PCR $(n=9)$} \\
\hline & & Higher median expression in & Fold change (median) $)^{\mathrm{a}}$ & $P$-value ${ }^{\mathrm{b}}$ \\
\hline $\mathrm{C}-\mathrm{C}$ motif chemokine ligand 18 & CCL18 & Choriodecidual leukocytes & 5691.58 & $<0.001$ \\
\hline Glycoprotein nmb & $G P N M B$ & Choriodecidual leukocytes & 477.82 & $<0.001$ \\
\hline Selenoprotein $\mathrm{P}$ & SEPP1 & Choriodecidual leukocytes & 1507.69 & $<0.001$ \\
\hline Fibronectin 1 & FN1 & Choriodecidual leukocytes & 1198.83 & $<0.001$ \\
\hline Ribonuclease A family member 1 , pancreatic & RNASE1 & Choriodecidual leukocytes & 952.14 & $<0.001$ \\
\hline Secreted phosphoprotein 1 & $S P P 1$ & Choriodecidual leukocytes & 157.86 & $<0.001$ \\
\hline Complement $\mathrm{C} 1 \mathrm{q} \mathrm{C}$ chain & $C 1 Q C$ & Choriodecidual leukocytes & 439.91 & $<0.001$ \\
\hline Phospholipid transfer protein & PLTP & Choriodecidual leukocytes & 466.74 & $<0.001$ \\
\hline
\end{tabular}

Genes with a differential expression of $\log \mathrm{FCh}>5$ and $B>3$

${ }^{\mathrm{a}}$ Fold change calculated with the $2^{-\Delta \Delta \mathrm{Ct}}$ method

${ }^{\mathrm{b}}$ Statistical differences were analyzed using Mann-Whitney $U$ tests

leukocyte recruitment during the process of labor. In other words, this data suggests that leukocytes infiltrating the choriodecidua trigger a positive feedback mechanism whereby more leukocytes are recruited into the maternalfetal interface.

To gain a deeper understanding of the biological processes up-regulated in the choriodecidual leukocytes from women who underwent spontaneous labor at term, analysis of functional protein association networks was performed with the eight most up-regulated genes (Supplementary Figure 2). Such analysis demonstrated that these genes do not have significant interactions. This means that the interactions between these genes/proteins are unknown or that they do not have a meaningful biological interaction. Since we did not find interactions among the eight most upregulated genes, gene ontology was performed in all of the up-regulated genes in the choriodecidual leukocytes. Figure 3 shows that the following biological processes were enriched in the choriodecidual leukocytes from women who underwent spontaneous labor at term: (Group 1) cell migration and regulation of immune response, (Group 2) chemotaxis, and (Group 3) humoral immune response.

The most up-regulated of these biological processes was the humoral immune response pathway, including T-cell and B-cell responses. Previously, we demonstrated that the chorioamniotic membranes can recruit $\mathrm{T}$ cells, which are implicated in the physiological [14-16] and pathological [51-55] processes of labor. Indeed, in vivo activation of $\mathrm{T}$ cells through the $\mathrm{CD} 3$ complex induces premature labor and delivery [56]. B cells can also be recruited by the chorioamniotic membranes [14] and constitute a portion of the choriodecidual leukocytes [16, 57, 58]. The role of B cells during pregnancy and its complications have been widely studied by Jensen and collaborators [59-68]. Taken together, these data provide further evidence that the adaptive limb of immunity is involved in the process of labor.

Choriodecidual leukocytes up-regulated the expression of genes involved in the complement activation pathway. Such a pathway has been implicated in susceptibility to viral infections [69] and the pathological process of preterm labor [70-74], but not in the physiological process of labor at term. Therefore, this finding requires further investigation.

The fact that choriodecidual leukocytes express transcripts implicated in the humoral immune response pathway is in line with previous reports indicating that visfatin, a preB-cell colony enhancing factor, is expressed in the decidua [75] and amniotic fluid [76] during the physiologic and infection-related pathologic processes of labor. Together, these data suggest that the humoral immune response pathway is implicated in the mechanisms of labor amplification and the host defense response against intra-amniotic infection.

Interestingly, the choriodecidual leukocytes overexpressed the peroxisome proliferator-activated receptor gamma (PPAR $\gamma$ ) during the process of labor. PPAR $\gamma$ is expressed in the choriodecidual tissues [77], including decidual macrophages [78], where it was suggested to participate in the process of labor [79]. Recently, we reported that PPAR $\gamma$ activation (via rosiglitazone) attenuates the pro-inflammatory response at the maternal-fetal interface induced by a microbial product [78] or activation of invariant natural killer T cells [55]. Altogether, these data suggest that the choriodecidual leukocytes express PPAR $\gamma$ in order to dampen the pro-inflammatory microenvironment that accompanies the process of labor.

A limitation of the current study is that the isolated choriodecidual leukocytes had a moderate purity $(>70 \%)$, which suggest that the gene expression reported, herein, 


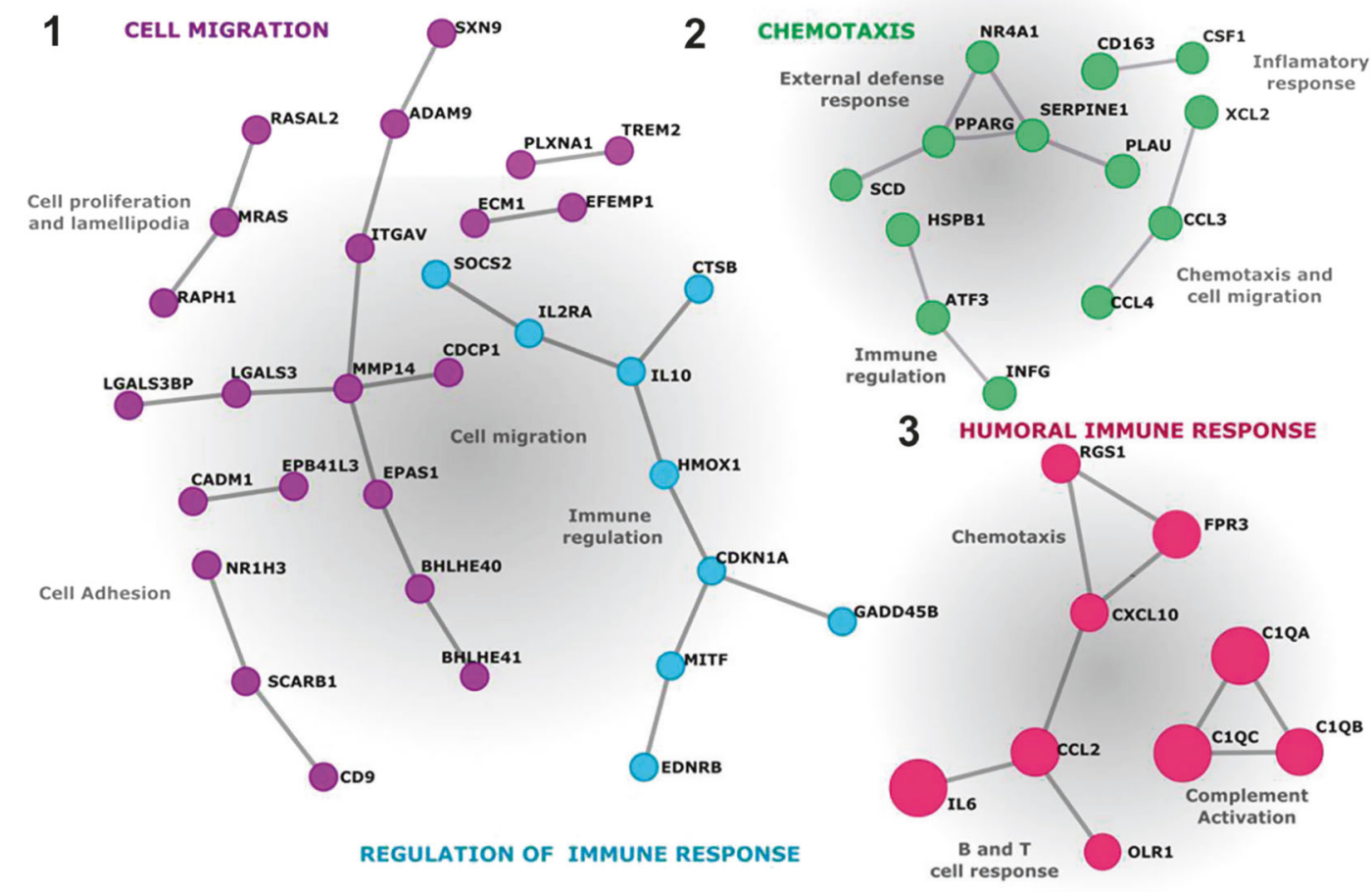

Fig. 3 STRING-based analysis representing up-regulated genes in the choriodecidual leukocytes from women who underwent spontaneous labor at term. The interaction networks show significantly up-regulated transcripts (fold change $>2$ and adjusted $p<0.001$ ) from microarray

may also include the transcripts expressed by decidual and stromal choriodecidual cells. Yet, most of the mediators reported herein are involved in immune responses.

In conclusion, this study demonstrated that there are transcriptomic differences between the choriodecidual leukocytes and maternal circulating leukocytes during the process of labor at term. The biological processes enriched in the choriodecidual leukocytes during the process of labor are: (1) cell migration and regulation of immune response, (2) chemotaxis, and (3) humoral immune response, which includes T-cell and B-cell responses. Collectively, these data show that there are striking differences between the transcriptome of the choriodecidual leukocytes and the transcriptome of maternal circulating leukocytes. The interaction network analysis revealed that the choriodecidual leukocytes are enriched in immune mediators implicated in the spontaneous process of labor at term.

\section{Materials and methods}

\section{Human samples and clinical definitions}

This study was approved by the Internal Review Board of the Instituto Nacional de Perinatología in Mexico City data. For functional enrichment analysis, the up-regulated genes were divided into three categories based on their fold change: Group 1: fold change $>2$ and $<5$, Group 2: fold change $>5$ and $<10$, and Group 3: fold change $>10$

(Register number 212250-02191). Maternal peripheral blood samples were collected within $30 \mathrm{~min}$ before delivery and the chorioamniotic membranes immediately after delivery from the same woman. Participants included healthy women who underwent spontaneous labor at term ( $>37$ weeks of gestation, calculated from the date of the last menstrual period) resulting in delivery. Labor was defined by the presence of regular uterine contractions and cervical changes $(>2 \mathrm{~cm})$. Five participants were included in the first phase of the study (microarrays) and nine participants were included in the second phase of the study (qRT-PCR). The demographic characteristics of the study population are shown in Table 3.

\section{Isolation of maternal leukocytes}

Maternal circulating leukocytes were isolated using a density gradient (Polymorphprep; Axis-Shield, Oslo, Norway), according to the manufacturer's instructions. Mononuclear and polymorphonuclear leukocytes were collected and washed with $1 \times$ phosphate buffered saline (PBS). Red blood cells were lysed by incubating the leukocyte suspensions with erythrocyte lysis buffer (150 mM ammonium chloride, $10 \mathrm{mM}$ potassium bicarbonate, $0.1 \mathrm{mM}$ EDTA) for $15 \mathrm{~min}$ at room temperature. Leukocyte suspensions were 


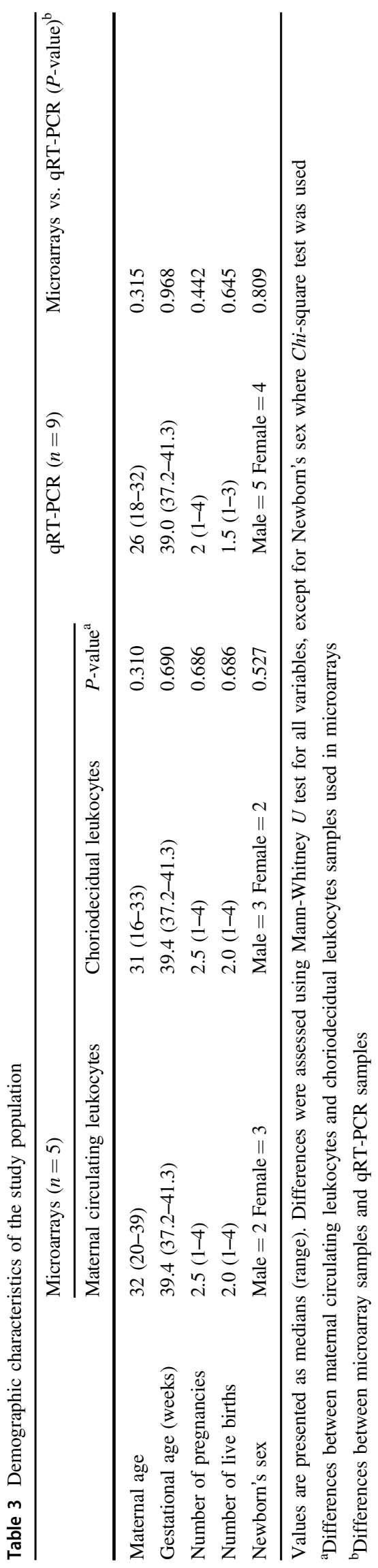

then washed with $1 \times$ PBS and the resulting cell pellet was resuspended in RNAlater solution (Ambion, Life Technologies, Carlsbad, CA, USA) and stored at $-80^{\circ} \mathrm{C}$. The entire process of isolation was performed using ice-cold buffers in order to minimize RNA degradation.

\section{Isolation of choriodecidual leukocytes}

Following collection of the chorioamniotic membranes, the amnion was separated from the chorion manually. Next, the entire chorion was cut into fragments (approximately $3 \times 3$ $\mathrm{cm}$ ), which were placed into a flask containing $50-100 \mathrm{~mL}$ of a digestion solution [Dubelcco's Modified Eagle Medium containing $0.1 \%$ of trypsin]. The flask was then incubated at $37^{\circ} \mathrm{C}$ for $5-10 \mathrm{~min}$ with low agitation. The volume of the digestion solution and the time of incubation depended on the size of the chorion. After incubation, the tissue suspension was filtered using sterile gauze and the flowthrough was collected. The resulting cell suspension was washed with $1 \times$ PBS and red blood cells were lysed using the erythrocyte lysis buffer, as previously described. Choriodecidual leukocytes were then isolated from other choriodecidual cells present in the cell suspension by magnetic cell sorting. Briefly, cell suspensions were incubated with a CD45 microbead-conjugated antibody and leukocytes (CD45+ cells) were isolated, according to the manufacturer's instructions (Miltenyi Biotec, Auburn, CA, USA). Purified choriodecidual leukocytes were stored at $-80{ }^{\circ} \mathrm{C}$ in RNAlater solution. The purity of choriodecidual leukocytes was $>70 \%$ of CD45+ cells (Supplementary Figure 1). The entire process of isolation was performed using ice-cold buffers to minimize RNA degradation.

\section{RNA isolation}

The TRIzol ${ }^{\circledR}$ reagent (Invitrogen, Life Technologies Corporation, Grand Island, NY, USA) was used to extract the total RNA from RNAlater solution-stored leukocytes, following the manufacturer's instructions. RNA purity and concentration were assessed with the 6000 NanoDrop $^{\circledR}$ spectrophotometer, and RNA integrity was evaluated with the Bioanalyzer 2100 (Agilent Technologies, Wilmington, DE, USA). RNA integrity numbers (RIN) were $>7$.

\section{cDNA synthesis}

For microarray experiments, $200 \mathrm{ng}$ of total RNA was amplified with the Ambion WT Expression kit, following the manufacturer's instructions (Ambion, Life Technologies, Carlsbad, CA, USA). Newly synthesized complementary (c)DNA was fragmented and labeled with the GeneChip ${ }^{\circledR}$ WT Terminal Labeling kit (Affymetrix, Santa 
Clara, CA, USA), according to the manufacturer's instructions.

For qRT-PCR experiments, $500 \mathrm{ng}$ of total RNA was used to generate cDNA using the Transcriptor First Strand cDNA Synthesis kit (Roche Applied Science, Mannheim, Germany) and random hexamers as primers. cDNA synthesis was carried out in a Mastercycler Gradient Thermalcycler (Eppendorf, Hamburg, Germany). Next, cDNA was stored at $-20{ }^{\circ} \mathrm{C}$ until use.

\section{Microarray analysis}

Five sets of matched samples from choriodecidual leukocytes and maternal circulating leukocytes were utilized for microarray analysis (Table 3). The GeneChip ${ }^{\circledR}$ Human Gene 1.0 ST array (Affymetrix Inc., Santa Clara, CA, USA) was used to measure the gene expression levels in each specimen, following manufacturer's instructions. This array included 28,869 well-annotated genes with 764,885 probes.

\section{Real-time quantitative polymerase chain reaction}

To validate the gene expression results from the microarray, eight up-regulated genes in choriodecidual leukocytes compared to maternal circulating leukocytes and two reference genes (Supplementary Table 1) were selected for qRT-PCR analysis. Validation was performed using a set of nine matched samples (choriodecidual leukocytes and maternal circulating leukocytes from nine different women). The expression analysis was performed by using the 48.48 Dynamic Array integrated fluidics chips (BioMark Fluidigm Corporation, San Francisco, CA, USA), following the manufacturer's instructions.

\section{Statistical analyses}

Raw microarray data were background-corrected using the Robust multi-array average (RMA) method [80], and normalized using the Quantile Normalization method [81]. Differential expression was determined using statistical linear models with arbitrary coefficients; contrasts of interest were analyzed using the bioconductor library limma $[82,83]$. Correction for multiple hypotheses was applied using a false discovery rate (FDR). Genes were selected based on a log fold change $\geq 0.3$ and a B-statistic $\geq 3$.

Differential expression between experimental qRT-PCR data was determined with the $2^{-\Delta \Delta \mathrm{Ct}}$ method [84]. The qRTPCR data were non-normally distributed according to the Shapiro-Wilk test. The Mann-Whitney $U$ test was used for comparisons between groups. A $P$-value $\leq 0.05$ was considered statistically significant. The statistical analysis was performed using the SPSS version 20 software (IBM Corporation, North Castle, NY, USA).

\section{Interaction network analysis}

The functional network analysis for up-regulated genes in the tested conditions (fold change $>2$, adjusted $P<0.001$ ) was constructed using protein-protein associations using the STRING (Search Tool for the Retrieval of Interacting Genes) v.10.0 software [85]. The network was built using high-quality associations (interaction score $\geq 0.700$ ). Genes were grouped based on their fold change expression into three different groups: Group 1: fold change $>2$ and $<5$, Group 2: fold change $>5$ and $<10$, and Group 3: fold change $>10$. These groups were analyzed separately using the STRING v.10.0 software. Gene ontology annotation was added to the graph based on the functional enrichment analysis results for the analyzed genes.

\section{Data availability}

All of the data are available in the tables and figures of the manuscript. Microarray data is available upon request at $r$. vega@inper.mx / vegarodrig@gmail.com

Acknowledgements We gratefully acknowledge Jorge Beltran Montoya, Rolando Maida Claros, Raul Mojica-Espinosa, Juan Pablo Aragon, and Karla MacDonald-Ramos for their contributions to the execution of this study.

Author contributions MAH, NGL, and RVS participated in the experimental design of the study; MAH and JAVP performed the experimental work; VGF, CRE, LMAS, and NMA performed the statistical analyses, and MAH, NGL, VGF, and RVS analyzed and interpreted the data and wrote the manuscript. All authors read and approved the final version of the manuscript.

Funding This study was funded by grant SALUD-2010-01-141144 from CONACYT and project 212250-02191 (RVS). NGL is supported by the Wayne State University Perinatal Initiative in Maternal, Perinatal, and Child Health. MAH was supported by a MSc scholarship and currently holds a doctoral scholarship both from CONACyT.

\section{Compliance with ethical standards}

Conflict of interest The authors declare that they have no competing interest.

Open Access This article is licensed under a Creative Commons Attribution-NonCommercial-ShareAlike 4.0 International License, which permits any non-commercial use, sharing, adaptation, distribution and reproduction in any medium or format, as long as you give appropriate credit to the original author(s) and the source, provide a link to the Creative Commons license, and indicate if changes were made. If you remix, transform, or build upon this article or a part thereof, you must distribute your contributions under the same 
license as the original. The images or other third party material in this article are included in the article's Creative Commons license, unless indicated otherwise in a credit line to the material. If material is not included in the article's Creative Commons license and your intended use is not permitted by statutory regulation or exceeds the permitted use, you will need to obtain permission directly from the copyright holder. To view a copy of this license, visit http://creativecommons. org/licenses/by-nc-sa/4.0/.

\section{References}

1. Romero R, Espinoza J, Goncalves LF, Kusanovic JP, Friel LA, Nien JK. Inflammation in preterm and term labour and delivery. Semin Fetal Neonatal Med. 2006;11:317-26.

2. Haddad R, Tromp G, Kuivaniemi H, Chaiworapongsa T, Kim YM, Mazor M, et al. Human spontaneous labor without histologic chorioamnionitis is characterized by an acute inflammation gene expression signature. Am J Obs Gynecol. 2006;195:394e1-24.

3. Norman JE, Bollapragada S, Yuan M, Nelson SM. Inflammatory pathways in the mechanism of parturition. BMC Pregnancy Childbirth. 2007;7:S7.

4. Romero R, Xu Y, Plazyo O, Chaemsaithong P, Chaiworapongsa $\mathrm{T}$, Unkel R, et al. A role for the inflammasome in spontaneous labor at term. Am J Reprod Immunol. 2016. https://doi.org/10. 1111/aji.12440.

5. Sisti G, Kanninen TT, Witkin SS. Maternal immunity and pregnancy outcome: focus on preconception and autophagy. Genes Immun. 2016;17:1-7.

6. Liggins G. Cervical ripening as an inflammatory reaction. Edinburgh: Churchill Livingstone; 1981.

7. Mackler AM, Iezza G, Akin MR, McMillan P, Yellon SM. Macrophage trafficking in the uterus and cervix precedes parturition in the mouse. Biol Reprod. 1999;61:879-83.

8. Osman I, Young A, Ledingham MA, Thomson AJ, Jordan F, Greer IA, et al. Leukocyte density and pro-inflammatory cytokine expression in human fetal membranes, decidua, cervix and myometrium before and during labour at term. Mol Hum Reprod. 2003;9:41-45.

9. Payne KJ, Clyde LA, Weldon AJ, Milford TA, Yellon SM. Residency and activation of myeloid cells during remodeling of the prepartum murine cervix. Biol Reprod. 2012;87:106.

10. Thomson AJ, Telfer JF, Young A, Campbell S, Stewart CJ, Cameron IT, et al. Leukocytes infiltrate the myometrium during human parturition: further evidence that labour is an inflammatory process. Hum Reprod. 1999;14:229-36.

11. Shynlova O, Nedd-Roderique T, Li Y, Dorogin A, Lye SJ. Myometrial immune cells contribute to term parturition, preterm labour and post-partum involution in mice. J Cell Mol Med. 2013;17:90-102.

12. Shynlova O, Tsui P, Dorogin A, Lye SJ. Monocyte chemoattractant protein-1 (CCL-2) integrates mechanical and endocrine signals that mediate term and preterm labor. J Immunol. 2008;181:1470-9.

13. Osman I, Young A, Jordan F, Greer IA, Norman JE. Leukocyte density and proinflammatory mediator expression in regional human fetal membranes and decidua before and during labor at term. J Soc Gynecol Investig. 2006;13:97-103.

14. Gomez-Lopez N, Estrada-Gutierrez G, Jimenez-Zamudio L, Vega-Sanchez R, Vadillo-Ortega F. Fetal membranes exhibit selective leukocyte chemotaxic activity during human labor. J Reprod Immunol. 2009;80:122-31.

15. Gomez-Lopez N, Vadillo-Perez L, Hernandez-Carbajal A, Godines-Enriquez M, Olson DM, Vadillo-Ortega F. Specific inflammatory microenvironments in the zones of the fetal membranes at term delivery. Am J Obs Gynecol. 2011;205:235. e15-235.e24.

16. Gomez-Lopez N, Vega-Sanchez R, Castillo-Castrejon M, Romero R, Cubeiro-Arreola K, Vadillo-Ortega F. Evidence for a role for the adaptive immune response in human term parturition. Am J Reprod Immunol. 2013;69:212-30.

17. Sindram-Trujillo A, Scherjon S, Kanhai H, Roelen D, Claas F. Increased T-cell activation in Decidua Parietalis compared to Decidua Basalis in uncomplicated human term pregnancy. Am J Reprod Immunol. 2003;49:261-8.

18. Lessin DL, Hunt JS, King CR, Wood GW. Antigen expression by cells near the maternal-fetal interface. Am J Reprod Immunol Microbiol. 1988;16:1-7.

19. Vince GS, Starkey PM, Jackson MC, Sargent IL, Redman CW. Flow cytometric characterisation of cell populations in human pregnancy decidua and isolation of decidual macrophages. J Immunol Methods. 1990;132:181-9.

20. Vargas ML, Santos JL, Ruiz C, Montes MJ, Aleman P, GarciaTortosa C, et al. Comparison of the proportions of leukocytes in early and term human decidua. Am J Reprod Immunol. 1993;29:135-40.

21. Castrechini NM, Murthi P, Qin S, Kusuma GD, Wilton L, Abumaree M, et al. Decidua parietalis-derived mesenchymal stromal cells reside in a vascular niche within the choriodecidua. Reprod Sci. 2012;19:1302-14.

22. Gomez-Lopez N, StLouis D, Lehr MA, Sanchez-Rodriguez EN, Arenas-Hernandez M. Immune cells in term and preterm labor. Cell Mol Immunol. 2014;11:571-81.

23. Gomez-Lopez N, Vadillo-Perez L, Nessim S, Olson DM, VadilloOrtega F. Choriodecidua and amnion exhibit selective leukocyte chemotaxis during term human labor. Am J Obs Gynecol. 2011;204:364.e9-16.

24. Gomez-Lopez N, Hernandez-Santiago S, Lobb AP, Olson DM, Vadillo-Ortega F. Normal and premature rupture of fetal membranes at term delivery differ in regional chemotactic activity and related chemokine/cytokine production. Reprod Sci. 2013;20:276-84

25. Gomez-Lopez N, Tong WC, Arenas-Hernandez M, Tanaka S, Hajar O, Olson DM, et al. Chemotactic activity of gestational tissues through late pregnancy, term labor, and RU486-induced preterm labor in Guinea pigs. Am J Reprod Immunol. 2015;73:341-52.

26. Gomez-Lopez N, Tanaka S, Zaeem Z, Metz GA, Olson DM. Maternal circulating leukocytes display early chemotactic responsiveness during late gestation. BMC Pregnancy Childbirth. 2013;13:S8.

27. Yuan M, Jordan F, McInnes IB, Harnett MM, Norman JE. Leukocytes are primed in peripheral blood for activation during term and preterm labour. Mol Hum Reprod. 2009;15:713-24.

28. Vega-Sanchez R, Gomez-Lopez N, Flores-Pliego A, ClementeGalvan S, Estrada-Gutierrez G, Zentella-Dehesa A, et al. Placental blood leukocytes are functional and phenotypically different than peripheral leukocytes during human labor. J Reprod Immunol. 2010;84:100-10.

29. Galicia JC, Henson BR, Parker JS, Khan AA. Gene expression profile of pulpitis. Genes Immun. 2016;17:239-43.

30. Hussman JP, Beecham AH, Schmidt M, Martin ER, McCauley JL, Vance JM, et al. GWAS analysis implicates NF-kappaBmediated induction of inflammatory $\mathrm{T}$ cells in multiple sclerosis. Genes Immun. 2016;17:305-12.

31. Kruse A, Martens N, Fernekorn U, Hallmann R, Butcher EC. Alterations in the expression of homing-associated molecules at the maternal/fetal interface during the course of pregnancy. Biol Reprod. 2002;66:333-45.

32. Osman I, Crawford M, Jordan F, Young A, Norman J, Thomson A. Expression and localization of cell adhesion molecules in 
human fetal membranes during parturition. J Reprod Immunol. 2004;63:11-21.

33. Gomez-Lopez N, Guilbert LJ, Olson DM. Invasion of the leukocytes into the fetal-maternal interface during pregnancy. $\mathrm{J}$ Leukoc Biol. 2010;88:625-33.

34. Hamilton SA, Tower CL, Jones RL. Identification of chemokines associated with the recruitment of decidual leukocytes in human labour: potential novel targets for preterm labour. PLoS ONE. 2013;8:e56946.

35. Castillo-Castrejon M, Meraz-Cruz N, Gomez-Lopez N, FloresPliego A, Beltran-Montoya J, Viveros-Alcaraz M, et al. Choriodecidual cells from term human pregnancies show distinctive functional properties related to the induction of labor. Am J Reprod Immunol. 2014;71:86-93.

36. Vadillo-Ortega F, Gonzalez-Avila G, Furth EE, Lei H, Muschel RJ, Stetler-Stevenson WG, et al. 92-kd type IV collagenase (matrix metalloproteinase-9) activity in human amniochorion increases with labor. Am J Pathol. 1995;146:148-56.

37. Mitchell MD, Romero RJ, Edwin SS, Trautman MS. Prostaglandins and parturition. Reprod Fertil Dev. 1995;7:623-32.

38. Peltier MR. Immunology of term and preterm labor. Reprod Biol Endocrinol. 2003;1:122.

39. Repnik U, Tilburgs T, Roelen DL, van der Mast BJ, Kanhai HHH, Scherjon S, et al. Comparison of Macrophage phenotype between Decidua Basalis and Decidua Parietalis by flow cytometry. Placenta. 2008;29:405-12.

40. Tilburgs T, Scherjon SA, Roelen DL, Claas FHJ. Decidual CD8+ CD28- T cells express CD103 but not perforin. Hum Immunol. 2009;70:96-100.

41. Young A, Thomson AJ, Ledingham M, Jordan F, Greer IA, Norman JE. Immunolocalization of proinflammatory cytokines in myometrium, cervix, and fetal membranes during human parturition at term. Biol Reprod. 2002;66:445-9.

42. Gustafsson C, Hummerdal P, Matthiesen L, Berg G, Ekerfelt C, Ernerudh J. Cytokine secretion in decidual mononuclear cells from term human pregnancy with or without labour: ELISPOT detection of IFN-gamma, IL-4, IL-10, TGF-beta and TNF-alpha. J Reprod Immunol. 2006;71:41-56.

43. Tilburgs T, Schonkeren D, Eikmans M, Nagtzaam NM, Datema G, Swings GM. et al. Human Decidual tissue contains differentiated CD8+ effector-memory $\mathrm{T}$ cells with unique properties. $\mathrm{J}$ Immunol. 2010;185:4470-7.

44. Butterworth BH, Greer IA, Liston WA, Haddad NG, Johnston TA. Immunocytochemical localization of neutrophil elastase in term placenta decidua and myometrium in pregnancy-induced hypertension. Br J Obs Gynaecol. 1991;98:929-33.

45. Gomez-Lopez N, Romero R, Xu Y, Plazyo O, Unkel R, Than NG, et al. A Role for the inflammasome in spontaneous labor at term with acute histologic chorioamnionitis. Reprod Sci. 2016;24:934-953. 1933719116675058.

46. Lim R, Barker G, Lappas M. Human cathelicidin antimicrobial protein 18 (hCAP18/LL-37) is increased in foetal membranes and myometrium after spontaneous labour and delivery. J Reprod Immunol. 2015;107:31-42.

47. Sindram-Trujillo AP, Scherjon SA, Miert PP, van H, Kanhai HHH, Roelen DL, Claas FHJ. Comparison of decidual leukocytes following spontaneous vaginal delivery and elective cesarean section in uncomplicated human term pregnancy. J Reprod Immunol. 2004;62:125-37.

48. Tilburgs T, Roelen DL, van der Mast BJ, van Schip JJ, Kleijburg C, de Groot-Swings GM, et al. Differential distribution of CD4(+) CD25(bright) and CD8(+)CD28(-) T-cells in decidua and maternal blood during human pregnancy. Placenta. 2006;27: S47-53.

49. Tilburgs T, van der Mast BJ, Nagtzaam NMA, Roelen DL, Scherjon SA, Claas FHJ. Expression of NK cell receptors on decidual $\mathrm{T}$ cells in human pregnancy. $\mathrm{J}$ Reprod Immunol. 2009;80:22-32.

50. Horton JS, Yamamoto SY, Bryant-Greenwood GD. Relaxin modulates proinflammatory cytokine secretion from human decidual macrophages. Biol Reprod. 2011;85:788-97.

51. Jacques SM, Qureshi F. Chronic chorioamnionitis: a clinicopathologic and immunohistochemical study. Hum Pathol. 1998;29:1457-61.

52. Kim CJ, Romero R, Chaemsaithong P, Kim JS. Chronic inflammation of the placenta: definition, classification, pathogenesis, and clinical significance. Am J Obs Gynecol. 2015;213:S53-69.

53. Kim MJ, Romero R, Kim CJ, Tarca AL, Chhauy S, LaJeunesse C, et al. Villitis of unknown etiology is associated with a distinct pattern of chemokine upregulation in the feto-maternal and placental compartments: implications for conjoint maternal allograft rejection and maternal anti-fetal graft-versus-host disease. J Immunol. 2009;182:3919-27.

54. Kim JS, Romero R, Kim MR, Kim YM, Friel L, Espinoza J, et al. Involvement of Hofbauer cells and maternal $\mathrm{T}$ cells in villitis of unknown aetiology. Histopathology. 2008;52:457-64.

55. St Louis D, Romero R, Plazyo O, Arenas-Hernandez M, Panaitescu $\mathrm{B}, \mathrm{Xu} \mathrm{Y}$, et al. Invariant NKT cell activation induces late preterm birth that is attenuated by rosiglitazone. J Immunol. 2016;196:1044-59.

56. Gomez-Lopez N, Romero R, Arenas-Hernandez M, Ahn H, Panaitescu B, Vadillo-Ortega F, et al. In vivo T-cell activation by a monoclonal alphaCD3epsilon antibody induces preterm labor and birth. Am J Reprod Immunol. 2016;76:386-90.

57. Xu Y, Plazyo O, Romero R, Hassan SS, Gomez-Lopez N. Isolation of leukocytes from the human maternal-fetal interface. $J$ Vis Exp. 2015;99:e52863.

58. Arenas-Hernandez M, Sanchez-Rodriguez EN, Mial TN, Robertson S, Gomez-Lopez N. Isolation of leukocytes from the murine tissues at the maternal-fetal interface. J Vis Exp. 2015;99:e52866.

59. Jensen F, Wallukat G, Herse F, Budner O, El-Mousleh T, Costa $\mathrm{SD}$, et al. CD19+ CD5+ cells as indicators of preeclampsia. Hypertension. 2012;59:861-8.

60. Bommer I, Muzzio DO, Zygmunt M, Jensen F. Progesterone and estradiol exert an inhibitory effect on the production of antiinflammatory cytokine IL-10 by activated MZ B cells. J Reprod Immunol. 2016;116:113-6.

61. Muzzio DO, Soldati R, Ehrhardt J, Utpatel K, Evert M, Zenclussen AC, et al. B cell development undergoes profound modifications and adaptations during pregnancy in mice. Biol Reprod. 2014;91:115

62. Muzzio D, Zenclussen AC, Jensen F. The role of B cells in pregnancy: the good and the bad. Am J Reprod Immunol. 2013;69:408-12.

63. Muzzio DO, Soldati R, Rolle L, Zygmunt M, Zenclussen AC, Jensen F. B-1a B cells regulate $\mathrm{T}$ cell differentiation associated with pregnancy disturbances. Front Immunol. 2014;5:6.

64. Muzzio D, Zygmunt M, Jensen F. The role of pregnancyassociated hormones in the development and function of regulatory B cells. Front Endocrinol. 2014;5:39.

65. Jensen F, Muzzio D, Soldati R, Fest S, Zenclussen AC. Regulatory B10 cells restore pregnancy tolerance in a mouse model. Biol Reprod. 2013;89:90.

66. Rolle L, Memarzadeh Tehran M, Morell-Garcia A, Raeva Y, Schumacher A, Hartig R, et al. Cutting edge: IL-10-producing regulatory $\mathrm{B}$ cells in early human pregnancy. Am $\mathrm{J}$ Reprod Immunol. 2013;70:448-53.

67. Wolfson ML, Muzzio DO, Ehrhardt J, Franchi AM, Zygmunt M, Jensen F. Expression analysis of cannabinoid receptors 1 and 2 in $\mathrm{B}$ cells during pregnancy and their role on cytokine production. $\mathbf{J}$ Reprod Immunol. 2016;116:23-27. 
68. Muzzio DO, Ziegler KB, Ehrhardt J, Zygmunt M, Jensen F. Marginal zone B cells emerge as a critical component of pregnancy well-being. Reproduction. 2016;151:29-37.

69. Herrero R, Real LM, Rivero-Juarez A, Pineda JA, Camacho A, Macias J, et al. Association of complement receptor 2 polymorphisms with innate resistance to HIV-1 infection. Genes Immun. 2015;16:134-41.

70. Soto E, Romero R, Richani K, Espinoza J, Nien JK, Chaiworapongsa $\mathrm{T}$, et al. Anaphylatoxins in preterm and term labor. $\mathrm{J}$ Perinat Med. 2005;33:306-13.

71. Vaisbuch E, Romero R, Erez O, Mazaki-Tovi S, Kusanovic JP, Soto $\mathrm{E}$, et al. Fragment $\mathrm{Bb}$ in amniotic fluid: evidence for complement activation by the alternative pathway in women with intra-amniotic infection/inflammation. J Matern Fetal Neonatal Med. 2009;22:905-16.

72. Soto E, Romero R, Richani K, Yoon BH, Chaiworapongsa T, Vaisbuch E, et al. Evidence for complement activation in the amniotic fluid of women with spontaneous preterm labor and intra-amniotic infection. J Matern Fetal Neonatal Med. 2009;22:983-92.

73. Vaisbuch E, Romero R, Erez O, Mazaki-Tovi S, Kusanovic JP, Soto E, et al. Activation of the alternative pathway of complement is a feature of pre-term parturition but not of spontaneous labor at term. Am J Reprod Immunol. 2010;63:318-30.

74. Gonzalez JM, Dong Z, Romero R, Girardi G. Cervical remodeling/ripening at term and preterm delivery: the same mechanism initiated by different mediators and different effector cells. PLoS ONE. 2011;6:e26877.

75. Ognjanovic S, Bryant-Greenwood GD. Pre-B-cell colonyenhancing factor, a novel cytokine of human fetal membranes. Am J Obstet Gynecol. 2002;187:1051-8.

76 Mazaki-Tovi S, Romero R, Kusanovic JP, Erez O, Gotsch F, Mittal $\mathrm{P}$, et al. Visfatin/Pre-B cell colony-enhancing factor in amniotic fluid in normal pregnancy, spontaneous labor at term, preterm labor and prelabor rupture of membranes: an association with subclinical intrauterine infection in preterm parturition. J Perinat Med. 2008;36:485-96.

77. Marvin KW, Eykholt RL, Keelan JA, Sato TA, Mitchell MD. The 15-deoxy-delta(12,14)-prostaglandin J(2)receptor, peroxisome proliferator activated receptor-gamma (PPARgamma) is expressed in human gestational tissues and is functionally active in JEG3 choriocarcinoma cells. Placenta. 2000;21:436-40.

78. Xu Y, Romero R, Miller D, Kadam L, Mial TN, Plazyo O, et al. An M1-like macrophage polarization in decidual tissue during spontaneous preterm labor that is attenuated by rosiglitazone treatment. J Immunol. 2016;196:2476-91.

79. Berry EB, Eykholt R, Helliwell RJ, Gilmour RS, Mitchell MD, Marvin KW. Peroxisome proliferator-activated receptor isoform expression changes in human gestational tissues with labor at term. Mol Pharmacol. 2003;64:1586-90.

80. Irizarry RA, Hobbs B, Collin F, Beazer-Barclay YD, Antonellis $\mathrm{KJ}$, Scherf U, et al. Exploration, normalization, and summaries of high density oligonucleotide array probe level data. Biostatistics. 2003;4:249-64.

81. Bolstad BM, Irizarry RA, Astrand M, Speed TP. A comparison of normalization methods for high density oligonucleotide array data based on variance and bias. Bioinformatics. 2003;19:185-93.

82. Smyth GK. Linear models and empirical Bayes methods for assessing differential expression in microarray experiments. Stat Appl Genet Mol Biol. 2004;3:1-25.

83. Ritchie ME, Phipson B, Wu D, Hu Y, Law CW, Shi W, et al. limma powers differential expression analyses for RNAsequencing and microarray studies. Nucl Acids Res. 2015;43:e47

84. Livak KJ, Schmittgen TD. Analysis of relative gene expression data using real-time quantitative PCR and the 2(-Delta Delta C(T)) method. Methods. 2001;25:402-8.

85. Szklarczyk D, Franceschini A, Wyder S, Forslund K, Heller D, Huerta-Cepas J, et al. STRING v10: protein-protein interaction networks, integrated over the tree of life. Nucl Acids Res. 2015;43:D447-52. 